\title{
THE MEGACITY COMMONS: AN INVESTIGATION OF SÃO PAULO'S CONTRIBUTIONS TO THE KNOWLEDGE ON THE COMMONS ECONOMY
}

\section{Patricia Riccelli Galante de Sá}

Especialista em Sustentabilidade, Economia para Transição e Reputação Corporativa, tendo exercido cargos executivos trabalhando com empresas como Natura, Disney, TAM, Caesar Park e Louis Vuitton. ProfessoraConvidada dos MBA da FGV, Ibmec e UFRJ desde 1995.

Mestre em Administração pela FGV/EBAPE e pós-graduada em Economics for Transition pelo Schumacher College/Inglaterra.

\begin{abstract}
As the current neoliberal economic system, based on money and competition, is failing, the commons economy appears as a possible new arrangement to occupy its place. Half of humankind live in urban areas, a trend that will increase in the next 15 years - specially the growth of megacities. Brazil has two of them - São Paulo and Rio de Janeiro - where urban commons initiatives are flourishing, despite their lack of connection and visibility. This article explores the need for mapping, integration and creation of a governance structure to support and stimulate the urban commons in megacities, by using São Paulo as a case study. The scale, diversity and challenges offered by this type of environment can enrich and evolve the knowledge on the commons economy.
\end{abstract}

\section{Keywords}

Urban Commons. Megacities. Peer-to-Peer. Sharing Economy. Makers Movement. Fab Labs. Collaborative Consumption. Occupy Movement. Governance.

\section{OS 'COMMONS' NAS MEGACIDADES: UMA INVESTIGAÇ̃̃ DAS CONTRIBUIÇÕES DE SÃO PAULO PARA O CONHECIMENTO SOBRE A ECONOMIA DOS 'COMMONS'}

\begin{abstract}
Resumo
O atual sistema econômico neoliberal, baseado em dinheiro e competição, está falindo, e a economia dos 'commons' surge como um possível novo arranjo para substituí-lo. Metade da humanidade vive em áreas urbanas, tendência que deve aumentar nos próximos 15 anos - especialmente o crescimento de megacidades. O Brasil tem duas delas São Paulo e Rio de Janeiro - onde as iniciativas envolvendo bens coletivos urbanos estão florescendo, apesar da sua falta de conexão e visibilidade. Este artigo explora a necessidade de mapear, integrar e criar uma estrutura de governança que apoie e estimule os 'urban commons' em megacidades, usando São Paulo como estudo de caso. A escala, diversidade e desafios apresentados por esse tipo de ambiente podem enriquecer e evoluir o conhecimento sobre a economia dos bens comuns.
\end{abstract}

\section{Palavras-chave}

Bens Comuns. Megacidades. Peer-to-Peer. Economia Colaborativa. Movimento Makers. Fab Labs. Consumo Colaborativo. Movimento Occupy. Governança. 


\section{INTRODUCTION}

Born in Rio de Janeiro and living in São Paulo/Brazil, I have been witness to the contradictions and joys of megacities ${ }^{1}$ during my entire life. With a population of 21 million people, São Paulo is the world's $11^{\text {th }}$ biggest city according to Demographia's 2015 Index. Rio is $26^{\text {th }}$, with 12,2 million metropolitan inhabitants. These cities couldn't be more different in terms of geography and culture, and illustrate the diversity of Brazilian urban areas - each with its own challenges.

According to the United Nations, half of the world's 7 billion population live in urban areas of all sizes, $1 / 4$ in cities of more than 1 million people and $8 \%$ in megacities. And the percentage is only increasing each year. ${ }^{2}$ São Paulo will gain around 45.000 new citizens annually until 2030.

But not all megacities are alike. Reif ${ }^{3}$ establishes a difference between a megacity and a metropolis. The latter evokes not only population size, national and international prominence, but also a high level of complexity and interlinkages, structural wealth, human diversity, innovation potential and dynamism.

He defines three basic types of megacities:

1) traditional cities in Asia, Europe and the US ${ }^{4}$, with sound governance institutions, which have to manage rapid urban growth, increasing international flows of people (human diversity) and speculative capital, structural change by de-industrialization, consistent social exclusion and citizen's loss of access to public goods;

2) the 'mega-urbanization in poverty' or 'city yet to come' in the poor South ${ }^{5}$, where supply of even the most basic public goods is defficient due to a failing State, mega-agglomerations at slums and poverty abound, and establishing an institutional framework that enables social participation and inclusion is key;

3) In between are the new megacities in the threshold countries, large thriving economies that are integrated to the global markets, and combine a young and diverse migrant population, equipped

\footnotetext{
${ }^{1}$ According to Demographia, megacities are urban areas with more than 10,000.000 inhabitants (2015)

${ }^{2}$ Ibid. The United Nations forecasts a 1.1 billion increase in the urban population of the world in just 15 years. By $2030,60 \%$ of the world's people will live in urban areas. And, by 2050, two-thirds of all people will reside in cities. Approximately $95 \%$ of the urban growth - almost all of the new megacities — is expected to be outside the high-income world (Cox 2015)

${ }^{3}$ (Reif 2006 cited in Kreibich 2010: 3-4)

${ }^{4}$ Like Tokyo, Seul, London, Paris, Moscow,New York, Los Angeles (as per Demographia, 2015)

${ }^{5}$ Such as Mumbai, Lagos, Kinshasa, Dar es Salaam, Dhaka.
} 
with technology, capital, cultural vitality, but still face governance shortfalls and inequalities in the access to common goods. They have the qualities of a metropolis.

São Paulo and Rio are good examples of these. They became attractive to the global systems of financial capital accumulation, due to their prosperity and economic stability, compounded with urban and natural assets that can be appropriated at undervalued prices and integrated to international speculative processes (such as mega-events, revitalization of decadent areas, franchises of international museum brands $)^{6}$.

This article sheds light in the urban commoning trends taking place in São Paulo, a city that is increasingly a 'fab-lab' of social innovations and citizen movements, reclaiming the rehumanization and a more meaningful, green and rational use of the public spaces, perhaps because of the hugeness of its urban scope. The intention is to map the different initiatives happening there, verify the pre-conditions that seem to have enabled them and to what extent the existing institutional governance structures are adequate to help them flourish.

Measures taken by benchmark cities in urban commoning, like Bologna, Totnes or Mantova, although inspiring, seem insufficient to address these issues in a megacity environment.

It is clear that the issues can be very diverse amongst high-density cities. From food supply and a need to integrate the surrounding countryside to the urban area, to the social inequalities and huge mobility problems, some themes seem to be universal: the building of resilience for the future, a need for more connectedness and communication among the citizens and new forms of governance. ${ }^{7}$

Due to the scales involved, if connected through a well indexed shared online platform, and sheltered by an 'institutional umbrella' of some kind, the megacities could benefit immensely of a rich cross-fertilization of experiences and boost the urban commons movement to a whole new level. If the biggest players are in the game, the critical mass that would be generated might produce invaluable outcomes.

The concept of 'commons' means a new socially constructed order of experience, that transcends the existing political and economical order with a new operational logic, grounded in

\footnotetext{
${ }^{6}$ Besides huge investments for the World Soccer Cup and Olympic Games, Rio de Janeiro just opened the high-tech Museu do Amanhã (Museum of Tomorrow), whilst public hospitals, schools and universities lack basic infrastructure, offer inhumane conditions and are near to closing down.

${ }^{7}$ Open Space 'Transition in High-Density Cities' during the Transition International Conference 2015; participants were from Hong-Kong, Stockholm, New York, New Orleans, São Paulo, London, Bangkoc, Bristol and Vietnam (no information of the city).
} 
human relations, production and governance. ${ }^{8}$ As Hess $^{9}$ points out, it is unclear if the commons are a 'movement', and the difficulty to define the term originates from the myriad of forms it assumes - from social movements to peer-to-peer economic exchanges, from neighbourhood associations to new forms of collective ownership, from intangible intellectual production to reconceptualizing physical assets, like gardens, products or streets. To that, she offers a comprehensive seven sectors/types categorization.

It also has a wide range of triggers, such as inneficient or untrustworthy governments, cultural lack of collective sense, imminent gentrification of public spaces, social inequalities/exclusion or personal income shrinking - all of them are true in São Paulo. Heiss uses the term 'New Commons' or 'non-conventional common-pool-resources' to define new forms of self-governance, collaboration and collective action that are taking place under the umbrella of the commons.

The tension between the privatization versus commodification of shared resources is very apparent in the metropolis, with great competition for intangible (i.e. cultural production, silence) and physical capabilities (like urban zoning limitations or competition for space by different modes of transportation and pedestrians). An iconic example was Banksy's artistic 31 days 'invasion' of New York. Was the street art produced by him an everlasting, valuable, collective cultural asset of the community, or a property of the buildings' owners, who either painted over the work or cut the pieces of wall and sold them at art galleries for huge money? ${ }^{10}$

The current legal framework is ill prepared to deal with such unprecedent occurences. The protection of common goods from enclosure by private interests is one of the most challenging debates of experts today. ${ }^{11}$ When Itaú Bank sponsored renowned danish architect Jan Ghel's ${ }^{12}$ revitalization project for historical Anhangabaú Valley in downtown S.Paulo, and donated it to the City Hall, questions were raised whether it had properties in the area and would further profit from speculation.

The 'Market/State duopoly' ${ }^{13}$ has been historically fruitful for both, but not so much for society, and now it's evident that the State doesn't in fact represent the sovereign will of people,

\footnotetext{
${ }^{8}$ (Bollier 2012: xiv)

${ }^{9}$ (Hess 2007). The sectors are: cultural commons; neighborhood commons; knowledge commons; social commons; infrastructure commons; market commons; and global commons.

${ }^{10}$ The action is shown in the film documentary 'Banksy does New York' (2014)

${ }^{11}$ (Bauwens 2015, Bauwens and Restakis 2014, Bollier 2012)

${ }^{12}$ Founder of City for People

${ }^{13}$ (Bollier 2012: xviii)
} 
is flawed and full of conflicts of interest at its very core - short term thinking, commercial attachments, pointless bureaucracy, unreliability to solve problems or even unethical behaviour, such as corruption or civil liberty constraints. ${ }^{14}$

The new commons will naturally require an original set of operating principles (including governance) and the development of a lexicon that can describe the phenomena and forge a new culture, tangibilizing and disseminating these new formats to ordinary people, de-mystifying them and training citizens and legislators on how to deal with the many social technologies and exchange arrangements, that are not yet widespread or fully understood. ${ }^{15}$

The commons' idea also depends heavily on everyone's belief that the benefits and sacrifices are being equally distributed and no one is being exploited. ${ }^{16}$ So, trust is a very key element to establish cooperation, and it can be achieved and increased by feedback mechanisms that show what is the likely behaviour of others, guaranteeing that everybody is bearing their fair share of the costs. But if trust is easy to develop in a small group, when it comes to large urban areas filled with strangers, it relies heavily in the just right amount of well-structured institutional regulation. Ostrom ${ }^{17}$ suggested key design principles to successfully stabilize the commons, and avoid 'reactants'.

The local space is where our identity if formed, where we defend what we feel and think, whereas the global space is the macro abstract place of power, which has always tried to control the local space. ${ }^{18}$ The possibility of physical contact between people is constantly being denied in the metropolis. There is a systematic destruction of the local public space, transformed into private areas organized around consumption and commerce (i.e. shopping centres, parking areas, business complexes). According to Lefebvre ${ }^{19}$, the 'right to the city' is the right to gather and occupy a space without having to pay, consume or have permission from any authority.

To Lefebvre ${ }^{20}$, the production of urban space entails not only the material planning of the place, but moreover the lifestyles and life stories that emerge in these places. The affective

\footnotetext{
14 (Castells 2013)

${ }^{15}$ The list of examples is impressive, and thus challenging: resource stewardship, collective enterprise, distributed manufacturing, community land trusts, time banks, alternative currencies, online affinity groups, intergenerational cooperation, right livelihood, co-production, care economy, sharing/solidary economy, collaborative consumption, co-work, co-production, intentional communities, urban resilience, transition towns, impact/social investment, economies of scope, co-housing, to name some.

16 (Ostrom 2009 cited in Beckencamp 2012: 24-27; Sankar, Zeynep and Morwitz 2001)

17 (Ostrom, 1990)

${ }^{18} \mathrm{Ibid}$. The global space is formed by the 'space of flows' (digital media, online financial markets, airplane routes and stock of hotel rooms).

19 (Lefebvre 1991)

${ }^{20}$ (Lefebvre 1991, cited in Purcell 2002: 102)
} 
significances, the traditions and the cultural symbols produced by the relationships among people and with the space. This means that anyone (be it local citizens with voting rights or transient inhabitants - such as expatriates, students or tourists), all help shape the place and have 'a right to the city' in their own and mutually respectful ways. Megacities, thus, are the most challenging melting pots of interculturality and diversity of demands.

Historically, urban inhabitants have been disenfranchised of the decision- making that shape their cities, with many of the state functions being progressively transferred to other bodies, such as supranational organizations or authonomous local governments. These have shifted from focus on societal demands and redistribution of wealth to a neoliberal imperative to emphasize capital accumulation and economic competitiveness in an international level investing in infrastructure to provide for the market (fast urbanization at the expense of green areas, education funds allocated do supply expert labour $)^{21}$, with the help of public-private partnerships, business councils and urban development corporations. This diffusion of governance creates a growing difficulty for citizens to direct their demands and have a voice. Gentrification and increasing economic/social inequalities represent a loss of the 'right to the city'.

\section{MAPPING THE COMMONS IN SÃO PAULO MEGACITY}

Three main vectors can cathegorize what's happening in São Paulo in the commons playfield: the Occupy movements, the re-humanization of physical urban spaces and the citizen's collaborative economy.

The 'São Paulo Cidade Colaborativa 2015' guide mapped the 100 main collaborative economy projects, divided into ten sectors ${ }^{22}$, finding out that culture, mobility and governance (NGOs and public government) concentrate $41 \%$ of the initiatives. But it's evident that many other projects happen under the radar, and altogether their contribution cannot be underrated, although they are scarcely online and take place in the lower income areas.

\section{Vector 1 - The Occupy Movements}

21 (Purcell 2002)

${ }^{22}$ Sectors are: environment, culture, food, housing, work, mobility, education, consumerism, services, NGOs/public authorities. The methodology used was an online search on the projects tagged as 'sharing' and further personal interview with each one. 
To Castells ${ }^{23}$, people's mass mobilizations are ignited by the emotional response to something that becomes unbearable and makes them overcome fear and take risks. In São Paulo, two different cases illustrate the citizens' radical reclaiming of the city: the homeless occupying abandoned buildings in downton areas, and students doing sit-ins in schools that were about to be closed by the government.

The city has a housing deficit of 230.000 units, and the increasing property prices deprive more and more people of a home. Real estate corporations buy or abandon land and old buildings (specially in derelict downtown areas), to later speculate when public authorities bring betterments, partly as a result of their heavy lobbying or priviledged information. The historical downtown area has undergone massive government investments to retrofit public properties and create cultural centres, ${ }^{24}$ amongst abandoned and semi-destroyed buildings, as result of company bankruptcies or land tax debts. The plan was to demolish and have them replaced by business towers and shopping malls. But the homeless had other plans, and invaded the buildings and partnered with Architecture and Law students; after years of legal battles and media exposure, the Mayor expropriated the properties and granted the inhabitants the freehold. ${ }^{25}$

In 2015, after the Governor announced that his new educational plan intended to close 94 public schools, displeased students occupied almost 200 of them for two months. With the moto 'Occupy and Resist' and inspired by the Chilean 'Penguins Revolution', the movement exposed the poor quality of the curriculum and lack of infrastructure, gained public support and made the authorities review their plans, incorporating suggestions from the students. Two lessons can be learned from this episode: how a 'public' resource can be re-signified as a 'commons' good and even upgraded by the citizens; and how these movements can be ignited by examples that come from across borders, highlighting the important role of communication.

\section{Vector 2 - The re-humanization of physical urban spaces}

Acclaimed urban activist Jane Jacobs ${ }^{26}$ saw cities as living beings and complex ecosystems, and advocated for their 'mindful' development, with empowered citizens defining

\footnotetext{
23 (Castells 2014)

${ }^{24}$ Estação da Luz, Pinacoteca do Estado, Museu da Lingua Brasileira and Viaduto do Chá.

${ }^{25}$ This was the case of Mauá 340, Prestes Maia 911 ( $2^{\text {nd }}$ biggest vertical occupation in Latin America) and Edifício União (awarded internationally for its renovation scheme)

26 (Jacobs 1992)
} 
their place, mixed-use and bottom-up planning. She was completely against 'slum-clearing' and 'high-rise housing' and the spacial segmentation of the city's uses, that destroy communities by creating isolated and anti-natural spaces and mobility overload. City Master Plans have historically given birth to social exclusion, gentrification, disintegration of social, economic and cultural tissues and value concentration in the hands of a privileged few.

Lefebvre $^{27}$ defended the right of the citizens to appropriate the urban space not only by using it, but and also by creating new ones to satisfy their needs. Communities establish talking points in neighbourhoods at spaces such as squares, sidewalks, beaches, when walking their dogs, practicing sports, forming baby groups, sitting in a park... It's during these encounters that the inhabitants create bonds, share narratives, frame culture and exchange ideas or skills. Re-shaping public spaces to be more welcoming, safe, beautiful and accessible is key to the urban commons. Many examples can be found in São Paulo.

The city was clearly designed for cars: $17.000 \mathrm{~km}$ of streets and avenues, only $150 \mathrm{~km}$ of bus corridors and a small subway net. The majority of its citizens use public transportation, but traffic is horrible, with cars occupying most of the space. Also, the spatial distribution of homes and offices, far from each other, has huge impacts on urban mobility.

The increase of bikers in the city shows that more people are in the process of bypassing the lack of structure provided by the State, making their own decisions on mobility and challenging the status quo. As a result, the government directed investments to extensive cycle paths and banned cars from main avenues on weekends. This may be a sign that other cracks in the system are under way, in other areas. Natália Garcia, from Cidade para Pessoas ${ }^{28}$, calls this 'hacking the city's governance', when citizens mould the space in a dispersed, organic way, creating a new model of life and influencing a permanent shift.

Greening the city is also huge, with the most diverse initiatives popping everywhere. From rooftop or communal food gardens, to car parking spaces and tiny hidden corners becoming mini-lounges for rest, meals and chats, with renewable energy outlets and recycled furniture (the Parklets and Pocket Gardens, part of the 'walkable city' concept); the unauthorized collective planting of flowers and trees in squares and river banks - in plain civil disobedience (i.e. movements 'A Batata Precisa de Você' and 'Mil Orquídeas Marginais'). Draughts and street flooding have been cyclic, and since the 1930's 300 rivers along $3.000 \mathrm{~km}$ were channelled and

\footnotetext{
27 (Lefebvre 1991)

28 'City for People'- http://cidadesparapessoas.com
} 
polluted by sewage leaks, to give way to 'progress'. Projects like 'Rios Invisíveis', 'Rios e Ruas' or 'Cidade Azul' aim to bring awareness of their existence, re-surface them and create a 'conversation' with the inhabitants, by painting in blue the streets over their courses, guided tours with Apps and plans to create promenades closed to cars.

\section{Vector 3 - Citizen's collaborative economy}

São Paulo's citizens are inventing new forms of work and spaces of collaborative activities. A city has limits to provide capital and resources for economic activities (job creation), leading to poverty, unemployment and depletion of natural ecosystems. By fostering the creative economy ${ }^{29}$ and entrepreneurship, it can overcome this limitation. As Gorenflo ${ }^{30}$ advocates, it's a matter of activating networked, peer-to-peer, value exchanges among individuals in direct relations, keeping income flowing inside the city; take underutilized spaces and use them for creative purposes. From street markets linking producers directly to consumers or barter fairs, to shared working spaces, the initiatives in São Paulo are diverse and creative. ${ }^{31}$

Like street events, from jazz shows to fancy Food Trucks and Chefs and Artists opening their back doors to the locals. Permanent Food Truck parks or festivals like 'Cozinha São Paulo' have spread throughout the city, offering entrepreneurs and independent cooks a livelihood, by nurturing an ample suppy chain of small producers, generating R $\$ 100$ millions/year in revenues. For nine years project 'Virada Cultural' offers 24 hours of round-the-clock free sustainable cultural events, scattered around public spaces in the city, aiming to make people appropriate them, specially those normally excluded from their use.

Curiously enough, co-housing schemes and ecovillages are still rare, maybe due to the lack of legal structures such as community land trusts and mutual home ownership societies.

\section{CONCLUSION - GRASSROOTS OR GRASSTOPS GOVERNANCE?}

Which would be the adequate governance structure to make the commons movement comprehensive and enduring in megacities, where there is the challenge of huge scope, need for

\footnotetext{
${ }^{29}$ Based on individual creativity, skills and talent to add value to goods, or entrepreneurship in the areas of culinary, music, art, crafts, desing, artistic performances, publishing, fashion etc.

30 (Gorenflo 2014)

${ }^{31}$ Such as indoor and outdoor co-working spaces, food truck pop-up festivals, street markets and barter fairs.
} 
scaling, impersonal linkages and excessive bureaucracy? 'A commons has a quality of just being there. Generally the rules for use are traditional and social, as opposed to formal and legalistic', says Rowe. ${ }^{32}$

The outdated grasstop ${ }^{33}$ framework - citizens outsourcing their agency to elected officials and privatization of public goods - must be replaced by 'the citizen actor' ${ }^{34}$, the creation of spaces for experimentation that bring people together and include the historically desinfranchised, formalizing informal activities, embracing the makers culture and open design, as fuels of innovation - all grassroots actions. Since December 2015, the São Paulo city government created twelve free high-tech fabrication labs for public school students - 'Fab Lab Livre'. The existence of innovation hubs at every district should be a public policy, and the collective intelligence should frame a diversity of solutions rather than the industrial paradigm of a single ideal answer of format.

To foster the sharing economy, the city must be regarded as a collaborative social ecosystem, not just an inventory of resources, with the government functioning as a hosting infrastructure to self-organized commons' initiatives. Rinne ${ }^{35}$ calls for the 'civic trifecta': better economics, better environment and better for community. The city's assets must be looked from a shared perspective, connecting those who 'want-have-can' (or people, companies and government), to activate the resources that the city already has ${ }^{36}$ and innovations that are "hidding in plain sight' (also from creative citizens living in poor communities). ${ }^{37}$ Map the assets that already exist in the city and no one is seeing, specially using the help of micro-level collaborators. Online platforms can be of great help to gather and spread information.

Megacities of the future should be 'metropolis of neighbourhoods ${ }^{38}$, where people know what others close by do or want. The community gives ideas for the use of public spaces, oriented by value rather than price, identifying what are the really relevant things and the interests at stake. Harvey calls it the collective right to reinvent the city. ${ }^{39}$ "A system that actively invites ordinary citizens and neighborhoods to invent their own urban commons, with the government's

\footnotetext{
32 (Rowe 2002 cited in Heiss 2008)

${ }^{33}$ Term coined by Rinne (2014) as synonym of top-down

34 (Rinne 2014)

35 (Rinne 2014)

36 (Garcia 2015)

37 (Rapson et al. No date)

38 (Guallart 2014)

39 (Harvey 2008 cited by Garcia 2015)
} 
active assistance ${ }^{40}$. It is the case of Minhocão ('big worm') viaduct, that in the verge of becoming a sort of High Line Park ${ }^{41}$, was 'invaded' spontaneouly and creatively by local inhabitants, becoming a meeting point for sports, strolls and cultural activities - even a gigantic 'swimming pool' was assembled. The Mayor banned cars and dropped the original gentrificating plans that would bring real estate speculation - a phenomena witnessed in areas such as the Meatpacking District (NY), the South Bank (London) and the Porto Maravilha (Rio) docklands.

Decisions should be taken in terms of asking: 'Will it improve or worsen the relationships among people?'. Rethink on what makes a city good or bad, as the current indicators are obsolete and based on the industrial/capitalist logic. According to The Economist, São Paulo is the world's fastest growing city in terms of competitiveness ${ }^{42}$. But how good is this, if also at the expense of high levels of mental and respiratory illnesses and medical leaves?

Urban planning needs to go beyond the current format of public consultation. Although the City Plan 2014 (until 2030) and the new Urban Zoning Law 2015 were made after extensive public engagement, most people don't understand their complexities, much less the impacts on the urban commons. See the case of Anhangabaú Valley's consultation through workshops and online polls: people argue that it was rather a harvest of suggestions to validate and polish a decision already taken in the governmental chambers, than a truly participatory process, wide enough to discuss the need for the project at all, and opt for other non-gentrificating alternatives, such as better conservation of the urban equipment, cleaning and security. The new Zoning Law, after 40 public hearings and 18 theme workshops, in efforts to solve the housing deficit and boost commercial activity, will threaten existing green areas and the cultural ambience of some important neighborhoods, presenting an embeded contradiction.

Although the initiatives in São Paulo are diverse and numerous, they are mostly concentrated in the more upscale areas of the city and organized by more educated people. The inhabitants of the periphery, with its slums and low income neighborhoods, also have a smaller participation in the open governance processes, except for confrontational situations with the public power. It is paramount to empower them, fostering the communication between all the different actors, clarifying the advantages, risks and setbacks of the commons possibilities.

\footnotetext{
40 (Bollier 2012)

41 Like the one in New York/USA.

42 (Garcia 2013)
} 
Funding of the different initiatives must embrace a diversity of formats beyond the governmental or public-private partnerships (NGOs, universities, philantropy, charge of moderate fees, grants, microcredit, crowdfunding, social investments etc), together with participatory budgeting. Co-production with government is also a novelty in the distribution and financing of public services. Each kind of Commons activity will recquire a different approach, and the use of the funds must happen in an open/transparent conversation.

It's essential to review the existing policies and laws, educate and sensibilize the government on the particularities of the commons economy, making it become an enabler, rather than an obstacle. Commoning needs regulation, to maximize the benefits, create trustworthy relationships and balance public needs. A more permanent legal protection must be in place, to compensate for the short term Mayors' mandates. The brazilian traditional 'hunger' for taxes and love of bureocracy are great obstacles to the more non-intermediated, informal and small scale collaborative economy.

Since the metropolis offers a major means of surplus accumulation, establishing a more democratic management over its urban deployment constitutes the 'right to the city', ${ }^{43}$ returning urbanization's command to the citizens.

The urban commons governance is not self-government, nor decentralization. It is rather distribution of powers among public, social, economic, knowledge and civic actors and therefore it implies a significant investment in the design of new forms of collaboration and partnerships among these actors. ${ }^{44}$

Governance in a complex ecossystem such as a megacity must be prepared to deal with both flux and chaos, thus have flexibility to tacke the disruptive nature of small-scale emerging initiatives, adapting to novelty and being redesigned over time.

If commoning stands the test of the megacities' environment, each with its own specificity, then we may witness a real economic revolution. Cross-studies encompassing all three types of megacities must be developed.

I finalize by borrowing Lefebvre's idea that the revolution has to be urban in the broadest sense of the term, or nothing at all!

${ }^{43}$ (Harvey 2008)
${ }^{44}$ Opening statement of The City as Commons conference/Bologna, 2015. 


\section{REFERENCES}

1 st IASC Thematic Conference on the Urban Commons. 'Ten points on the city as commons.' Labgov. 03 December 2015. Available in: <http://www.labgov.it/ten-points-on-the-city-ascommons>. Accessed in: 11 january 2016.

- 'The City as Commons Homepage'. Labgov. Available in:

<http://www.labgov.it/urbancommons>. Accessed in: November 2015.

BANKSY. Banksy does New York. (17 November 2014) Film. Director Chris Moukarbel. HBO Films. Video, 1:30 hour.

BARBER, B. 'Why Mayors should rule the world' TED Edinburg. June 2013. Available in: < http://video-subtitle.tedcdn.com/talk/podcast/2013G/None/BenjaminBarber_2013G-480p-ptbr.mp4>. Video, 18 minutes.

BAUWENS, M. speaker. 'Transformative proposals of the p2p foundation'. YouTube. 24 June 2015. Available in: 〈https://www.youtube.com/watch?v=sO-QJLDpHQ0>. Video, 20 minutes. Accessed in: 12 October 2015.

BAUWENS, M. and Restakis, J. 'Introducing the new configuration between the state, civil society and markets'. P2P e Inovação, n. 1 (Sep/Dec 2014) [Online] Available in:

<http://revista.ibict.br/index.php/p2pinovacao/article/view/2235/1821>. Brasil: Ibict publisher.

BOLLIER, D. and Helfrich, S. The wealth of the commons. 2012 . UK: The Commons Strategy

Group. [Online] Available in: 〈http://wealthofthecommons.org/contents>. Accessed in: 04 December 2015.

. Patterns of Commoning. UK: Levellers Press, 2015.

BECKENKAMP, M. 'Institutions and Trust in Commons: dealing with social dilemma'. The Wealth of the Commons - a world beyond market \& state. Ed. Bollier, D. and Helfrich, S. Amherst, MA: Levellers Press, 2012.

DE CORTICO em ruínas a vencedor de premio internacional de moradia'. Brasil de Fato. 8 September 2015. Available in: 〈http://brasildefato.com.br/node/32870>. Accessed in: 6 December 2015.

. 'Vida em ocupacão: a luta por moradia em S.Paulo'. Brasil de Fato. 8 September 2015. Available in: 〈http://brasildefato.com.br/node/32867>. Accessed in: 6 December 2015.

.'Segunda maior ocupacão vertical da América Latina abriga quase 400 famílias'. Brasil de Fato. 8 September 2015. Available in: 〈http://brasildefato.com.br/node/32869〉. Accessed in: 6 December 2015.

C40. History. Available in: <http://www.c40.org/history>. Accessed in: 14 December 2015. 
CASTELLS, M. 'Por um Brasil que desconhecemos'. Fronteiras do Pensamento. 25 Junho 2013. Youtube. Available in: <https://www.youtube.com/watch?v=YYAu2MA4yMI>. Accessed in: 15 December 2015.

Fronteiras do Pensamento. Youtube. Available in:

<https://www.youtube.com/watch?v=n01-dDhdLc4>. Accessed in: 15 December 2015.

. 'The Rise of the Network Society'. In: The Information Age: Economy, Society and Culture. V1. 2.ed. Oxford, UK: Blackwell Publishing, 2000.

COX, W. 'The world's ten largest megacities'. Huffington Post. 17 February 2015. Available in: <http://www.huffingtonpost.com/wendell-cox>. Accessed in: 14 December 2015.

DEMOGRAPHIA. World Megacities. World Urban Areas Index 2015. Demographia. Available in: http://www.demographia.com/db-megacity.pdf>. Accessed in: 14 December 2015.

DODD, M. 'Creative Cities: Managing Chaos not Cleaning up Mess.' Cultures of Resilience . Available in: <http://www.culturesofresilience.org/wordpress/?p=206>. Accessed in: 4 January 2016.

CONHECA os bastidores da ocupacão das escolas em São Paulo'. EBC. 14 December 2015. Available in: <http://www.ebc.com.br/educacao/2015/12/caminhos-da-reportagem-trazbastidores-da-ocupacao-das-escolas-em-sp-assista>. Accessed in: 15 December 2015.

SÃO PAULO ganhará 45 mil habitantes por ano até 2030’' Folha de S.Paulo. 1 January 2014. Available in: <http://www1.folha.uol.com.br/cotidiano/2014/01/1401210-sao-paulo- ganhara-45mil-habitantes-por-ano-ate-2030.shtml>. Accessed in: 14 December 2015.

GARCIA, N. speaker 'Cidade Reinventada'. Cidades para Pessoas. 16 Semptember 2015. http://cidadesparapessoas.com/cidade-reinventada/ [15 December 2015]

. speaker. 'Cidades para Pessoas: Natália Garcia - TEDxFloripa'. TED Talks. Youtube. 16 December 2013. Available in: <https://www.youtube.com/watch?time_ continue $=1065 \& v=G N a o v n 4 t a 7 M>$. Accessed in: 15 December 2015. Video, 17:45 minutes.

GORENFLO, N. speaker. 'Building a Network of Sharing Cities'. OuiShareTV. Youtube.

Available in: <https://www.youtube.com/watch?v=KkZZlSHU8-E>. Accessed in: 11 June 2014. Video, 12:33 minutes

GUALLART, V. speaker. 'The Self-Sufficient City'. OuiShareTV [Online]. Youtube. Available in: 〈https://www.youtube.com/watch?v=dfn-0b8yJe8>. Accessed in: 11 June 2014. Video, 13:16 minutes

HARVEY, D. 'The right to the city'. New Left Review 53, September- October 2008, 23-53.

HESS, C. Mapping the New Commons. DLC. 19 June 2008. Available in:

<http://dlc.dlib.indiana.edu/dlc/bitstream/handle/10535/304/Mapping_the_Ne wCommons.pdf>. Accessed in: 10 january 2016. 
HOPKINS, R. The Transition Handbook: From Oil Dependency to Local Resilience. UK: UIT Cambridge Ltd., 2014.

IBGE. Painel Cidades. IBGE. 2014. Available in: <http://cidades.ibge.gov.br/painel/ painel.php?codmun=330455>. Accessed in: 14 December 2015.

JACOBS, J. The death and life of great American cities. USA: Vintage, 1992.

KREIBICH, V. 'Metropolis: Our common future in the urban age.' In: KRULL, W.(Eds.):

Research and Responsibility. Reflections on our common future (2011) 97-110.

MOVIMENTO Boa Praca. Available in: 〈http://movimentoboapraca.com.br〉. Accessed in: 15 December 2015.

MOVIMENTO Cidade Colaborativa. 'Guia São Paulo Cidade Colaborativa 2015'. Cidade Colaborativa. 15 September 2015. Available in: <http://www.cidadecolaborativa.org/downloads/ guia-digital-cidade-colaborativa.pdf >. Accessed in: 10 March 2016. Brasil: GIG, Vitacon and ESPM publishers.

OBSERVATÓRIO das Metrópoles. 'Projeto Direito à Cidade'. Observatorio das metropoles. August 2015. Available in: <http://www.observatoriodasmetropoles.net/index.php? option=com_content $\&$ view $=$ article $\& i d=1780 \&$ Itemid $=179 \& l a n g=p t \#>$. Accessed in: 10 january 2016.

OSTROM, E. Governing the Commons: The Evolution of Institutions for Collective Action. UK: Cambridge University Press, 1990.

PURCELL, M. 'Excavating Lefebvre: The right to the city and its urban politics of the inhabitant.' Geo Journal 58 (2002) 99-108. Netherlands: Kluwer Academic Publishers, 2002.

RAPSON, R., BRADLEY, J., CLAY, A. and HIRSCHBERG, P. 'Is the next big urban innovation hiding in plain sight?'. Aspen Ideas Festival 2015. no date. Aspen Ideas Festival. Available in: <http://www.aspenideas.org/session/next-big-urban-innovation-hiding-plain-sight-aspen-policyseries>. Accessed in: 10 January 2016. Podcast, 45:28 minutes.

RINNE, A. 'Four ways cities can embrace the sharing economy'. World Economic Forum. 3 november 2014. Available in: <http://www.weforum.org/agenda/2014/11/four-ways-cities-canembrace- sharing-economy>. Accessed in: 13 january 2016.

. speaker 'Sharing Cities: Rethinking Urban Planning \& Sustainable Growth'

OuiShareTV. Youtube. 11 June 2014. Available in: <https://www.youtube.com/

watch? $v=x f d L g E q v 8 e U$ Video>. Accessed in: 12 January 2016. 14:33 minutes

ROY, A. 'The $21^{\text {st }}$ Century Metropolis: The Making of Urban Futures'. Essen: Our Common Future Conference (6 November 2010).

SANKAR, S., ZEYNEP, G.C. and MORWITZ, V. 'Withholding Consumption: a social dilemma perspective on consumer boycotts'. Journal of Consumer Research. 28 (December 2001). USA. 
TV Brasil. 'Anjos Rebeldes'. Youtube. 11 December 2015. Available in:

<https://www.youtube.com/watch?time_continue=1163\&v=necSPQchYXk>. Accessed in: 15 December 2015.

Wikipedia. 'Jane Jacobs' https://pt.wikipedia.org/wiki/Jane_Jacobs 